\author{
Murat Yaşar Özkalkanlı, \\ Fulya Yılmaz Duran, \\ Günay Yıldız, \\ Orhan Kılıç, \\ Onur Okur
}

\section{Drug Interaction Between Valproic Acid and Meropenem: A Case Report}

\author{
Valproik Asid ve Meropenem Arasındaki llaç Etkileşimi: \\ Olgu Sunumu
}

Received/Geliş Tarihi : 24.04.2014 Accepted/Kabul Tarihi : 23.12.2014

Journal of the Turkish Society of Intensive Care, published by Galenos Publishing Türk Yoğun Bakım Derneği Dergisi, Galenos Yayınevi tarafından basılmıştır. ISSN: 2146-6416

Murat Yaşar Özkalkanlı, Fulya Yılmaz Duran, Günay Yıldız, Orhan Kılıç, Onur Okur,

Bozyaka Training and Research Hospital, Clinic of Anaesthesiology and Reanimation, Izmir, Turkey

Fulya Yılmaz Duran ( $₫)$,

Bozyaka Training and Research Hospital, Clinic of Anaesthesiology and Reanimation, Izmir, Turkey

E-mail: drfulya@mynet.com

Phone: +90 23225050 50/2051
SUMMARY To report a probable interaction between meropenem and antiepileptic drugs that resulted in poor control of epileptic seizures. A previously healthy 21 years old woman admitted to emergency department with fever and stiff neck. Her Glasgow Coma Scale score was E3M5V4. Physical examination revealed conscious to tend to fall asleep, closed eyes and normal-sized and reactive pupils. Meropenem and vancomycin were initiated for the suspicion of menengitis. On the $3^{\text {rd }}$ day of the antibiotic therapy generalized tonic clonic seizures were observed. Phenytoin and intravenous (IV) thiopental were initiated. The patient was intubated and mechanically ventilated. EEG revealed generalized epileptiform activity. In the following days, seizure activity continued. Levetirasetam, carbamazepine and VPA were added for treatment respectively, but seizures were continued. On the $20^{\text {th }}$ day of meropenem therapy, interaction of carbapenems and anti-epileptic agents was suspected. Antibiotherapy was discontinued. Serum concentrations of VPA increased over the next days and achieved therapeutic levels. On day 21 she was extubated, no seizures occurred over the following 48 hours. She was discharged from the ICU, with blood anti epileptic concentrations within the therapeutic range. Carbapenems have a potential effect of inducing seizures and may also lower serum levels of antiepileptic drugs. Clinicians should be aware of this potential interaction that may be associated with serious adverse effects. Status epilepticus is one of the most important neurologic emergencies, and therapeutic control becomes more difficult as its duration becomes longer. Patients receiving antiepileptics and carbapenem group antibiotics concominantly should be closely monitored due to possible drug interaction between these agents.

Key Words: Meropenem, valproic acid, seizures, drug interaction

Conflicts of Interest: The authors reported no conflict of interest related to this article.
ÖZET Meropenem ve antiepileptik ilaçlar arasında olası bir etkileşim nedeniyle, epileptik nöbetin kontrolünün zor olduğu olgu bildirilmektedir. Daha önceden sağlıklı olduğu bildirilen 21 yaşında bayan hasta, ateş ve ense sertliği bulgularıyla acil servise başvurdu. Glasgow Koma skalası E3M5V4 idi. Fizik muayenesinde bilinç uykuya meyilli, gözler kapalı, pupiller normal boyutlarda ve reaktif idi. Menenjit şüphesiyle meropenem ve vankomisin tedavisi başlandı. Antibiotik tedavisinin 3. gününde jeneralize tonik klonik nöbet aktivitesi gözlendi. Fenitoin ve intravenöz tiopental tedavisi başlatıldı. Olgu entübe edilerek, mekanik ventilatörde izleme alındı. EEG'de generalize epileptiform aktivite gözlendi. Daha sonraki günlerde nöbet aktivitesi devam etti. Tedaviye sırasıyla levetirasetam, karbamazepine ve valproik asit (VPA) ilave edildi; fakat nöbet aktivitesi devam etti. Meropenem tedavisinin 20. gününde karbenepenem grubu ilaçlarla, antiepileptik ajanlar arasındaki ilaç etkileşiminden şüphelenildi. Antibiotik tedavisi sonlandırıldı. Sonraki birkaç gün içinde VPA seviyesi artarak, terapötik sınırlara ulaştı. Yirmi birinci günde ekstübe edildi. Sonraki 48 saat içinde nöbet aktivitesi gözlenmedi. Kan antiepileptik ilaç konsantrasyonları normal sınırlarda olarak, yoğun bakım ünitesinden taburcu edildi. Karbapenemler nöbet aktivitesini indüklerler ve serum antiepileptik ilac düzeyini düşürürüler. Klinisyenler ciddi yan etki oluşturabilecek bu potansiyel etkileşimin farkında olmalıdırlar. Status epileptikus önemli nörolojik acil durumlardan biridir ve nöbet süresi uzadıkça terapötik kontrolü zorlaşır. Antiepileptik ajanlarla birlikte karbapenem grubu antibiotik kullanan olgular, bu iki ilaç arasındaki olası ilaç etkileşiminden dolayı yakın takip edilmelidir.

Anahtar Kelimeler: Meropenem, valproik asit, nöbet, ilaç etkileşimi

Çıkar Çatıșması: Yazarlar bu makale ile ilgili olarak herhangi bir çıkar çatışması bildirmemiştir. 


\section{Introduction}

Status epilepticus (SE), is a major medical emergency associated with significant morbidity and mortality, is defined as a continuous, generalized, convulsive seizure lasting more than 5 minutes, or two or more seizures during which the patient doesn't return to baseline consciousness (1). Valproic acid (VPA), simple, branched-chain fatty acid with a broad spectrum of anticonvulsant activity, is commonly prescribed for treatment of various forms of epilepsy (2). It should be monitored becuse it has a narrow therapeutic blood margin (3). Meropenem is a bactericidal antibiotic with a broad spectrum of activity that is used fo a variety of infections (3). The interaction between these drugs is characterised by a rapid decline in VPA levels (4). We describe a patient who displayed a probable pharmacokinetic interaction between meropenem and antiepileptic drugs that resulted in the development of epileptic seizures.

\section{Case Report}

A previously healthy 21-year-old woman admitted to emergency department with fever and stiff neck. Her Glasgow Coma Scale score was E3M5V4 Physical examination revealed consciousness tend to fall asleep, closed eyes and normal-sized, normally reactive pupils. Cranial MRI findings were normal. The patient was admitted to intensive care unit. Blood cultures, complete blood count, C-Reactive Protein, blood chemistry and CSF samples were obtained. The patient was consulted with neurology and infectious disease doctors. Meropenem and vancomycin were started an initial for menengitis. On 3 rd day of the antibiotic theraphy generalized tonic clonic seizures were observed. Phenytoin and intravenous (IV) thiopental were started. Also, the patient was intubated and mechanically ventilated. EEG revealed generalized epileptiform activity. In the following days, seizure activity continued. Levetirasetam, carbamazepine and VPA were added for treatment respectively, but seizures continued. The patient was consulted with neurology and infectious disease doctors daily. Serum VPA and carbamazepine levels were lower than therapeutic levels although the drug doses were on upper limits. On the $20^{\text {th }}$ day of meropenem theraphy, interaction of carbapenems and anti-epileptic agents was suspected. Antibiotherapy was discontinued. Serum concentrations of VPA increased over the next days to achieve therapeutic levels. On day 21 she was extubated, no seizures had occured over the following 48 hours. She was discharged from the ICU, with blood anti epileptic concentrations within the therapeutic range.

\section{Discussion}

We have started treatment of IV meropenem with initial diagnosis of menengitis. On the 3 rd day of antibiotherapy epileptic seizures occured. With the diagnosis of SE patient was non-responsive to the various antiepileptics. Serum concentrations of antiepileptics were low during treatment. A possible drug interaction was suspected and meropenem therapy was terminated. Serum concentrations of antiepileptics reached therapeutic levels within 48 hours and seizures stopped.

Epilepsy, is defined as chronic neurologic condition charaterized by recurrent, unprovoked seizures. Status epilepticus is one of the most important neuologic emergencies and therapeutic control becomes more difficult as its duration becomes longer. VA, is one of the most frequently used drug in treatment of epilepsy. The main metabolic pathways are: $\beta$-oxidation $30-40 \%$, $\mathrm{N}$-glucuronidation 30-50\% and cytochrome P450 isoenzymes $10-15 \%$. Meropenem, is used as treatment for intraabdominal infections and meningitis in critically ill patients. Compared with imipenem, meropenem has a lower affinity for the $\gamma$-aminobutyric acid (GABA) receptor; thus, meropenem has a lower potential inducing seizures (2).

Seizures and other adverse CNS events have been reported during treatment with meropenem. These events have occured most commonly in patients with CNS disorders or with bacterial meningitis and/or compromised renal function. Seizure rate was $0.7 \%$ in patients treated for non-CNS infections with meropenem (5). Anti-convulsant therapy should be continued in patients with known seizures disorders. If seizure occurs, patients should be evaluated neurologically, placed on anti-convulsant therapy if not already instituted, and the dosage of meropenem re-examined to determine whether it should be decreased or the antibiotic discontinued. If administration of meropenem therapy is necessary, supplemental anticonvulsant therapy should be considered.

Recently, interactions between valproic acid and carbapenem antibiotics have been reported, in which the valproic acid serum concentrations have been reduced in epileptic patients. These patients received many drugs concomitantly with valproic acid, and serum concentrations of valproic acid fell only after carbapenem therapy was started. When carbapenem was stopped, the valproic acid plasma concentration increase. The mechanisms of the pharmacologic interaction between carbapenem and valproic acid is very complex. A decrease in the absorption of VPA, decrease in its enterohepatic recycling, a change in distribution volume reducing the free drug propotion and increase in VPA glucuronidation (3). This potental interaction 
not only increase the patient's morbidity and mortality, but also increase of health costs (2).

Klugman et al. reported that 5 of 82 patients receiving meropenem for treatment of bacterial menengitis, occured seizures during the therapy (6). But they reported that none were thought to be drug related. Cannon et al. reported that although imipenem was more epileptogenic than non-carbapenem antibiotics, there was no statistically significant difference in the imipenem versus meropenem head-to-head comparison (7). But Miller et al. reported for meropenem, doripenem, and ertapenem, the seizure rate for each agent is reported as less than $1 \%(8)$. Due to the drug interaction between carbapenems and valproic acid, resulting in clinically significant declines in valproic acid serum concentrations and can cause seizures.

Baraboutis et al. reported a case report of meropenemassociated seizures developing in a 15-year-old girl who had a history of progressive myoclonic epilepsy (9). Her initial electroencephalogram showed a high frequency of generalized spike-and-wave discharges. After receiving multiple antibiotics for pneumonia and persistent fever, her antibiotic regimen was changed to teicoplanin and meropenem $1 \mathrm{~g}$ every 8 hours on hospital day 3 . The patient's initial seizures improved before meropenem initiation; however, on hospital day 6 (3 days after drug initiation), the patient had a seizure relapse and required an increase in her antiepileptic drug dosage. Meropenem was discontinued, and the patient's seizures subsequently improved by hospital day 12; she returned to her baseline mental status on hospital day 16 . Of note, the patient was receiving concomitant valproic acid therapy. However, the authors reported that the patient maintained therapeutic levels throughout meropenem treatment.
In our patient, we started meropenem therapy with the initial of menegitis, and probably meropenem resulted in SE. The interaction between meropenem and VPA caused decrease in serum levels of VPA. During this period, serum levels of VPA (3.51-23.73-3-5.99 mcg/ml) and carbamazepine (0.51-0.87-1.77-0.87-1.67 ug/ml) did not reach therapeutic concentrations although combined therapy of antiepileptic drugs. However, we couldn't have meropenem blood concentration of the patient.

Carbapenems have a potential effect of inducing seizures and may also lower serum levels of antiepileptic drugs. Clinicians should be aware of this potential interaction that may be associated with a serious adverse effects. This case report, provides strong evidence for potential epileptic activity of meropenem and drug interaction between antiepileptic drugs and meropenem. Clinicans must take care of this interaction because of economic and clinical repercussions. In patients receiving antiepileptic drugs and carbapenem antibiotics together, serum concentration of antiepileptic drugs should be monitored. If possible, the concomitant use of these both drugs should be avoided.

\section{Conclusion}

SE is one of the most important neurologic emergencies, and therapeutic control becomes more difficult as its duration becomes longer. Patients receiving antiepileptics and carbapenem group antibiotics concominantly should be closely monitored due to possible drug interaction between these agents.

\section{References}

1. Karaaslan K, Gümüş E, Gülcü N, Altunrende B. Treatment of Refractory Generalized Status Epilepticus with Propofol (Case Report) Düzce Tıp Fakültesi Dergisi 2008;3:53-6.

2. Coves-Orts FJ, Borras-Blasco J, Navarro-Ruiz A, Murcia-Lopez A, Palacios-Ortega F. Acute Seizures Due to a Probable Interaction Between Valproic Acid and Meropenem. Ann Pharmacother 2005;39:533-7.

3. Velez-diaz-Pallares M, Delgado Silveira E, Alvarez Diaz AM, Perez Menendez-Conde C, Vicente Oliveros N, Bermejo Vicedo T. Analysis of the valproic acid-meropenem interaction in hospitalised patients. Neurologia 2012;27:34-8.
4. Spriet I, Meersseman W, De troy E, Wilmer A, Casteels M, Willems L. Meropenem-valproic acid interaction in patients with cefepime-associated status epilepticus. Am J Health Syst Pharm 2007;64:54-8

5. Linden P. Safety profile of meropenem: an updated review of over 6,000 patients treated with meropenem. Drug Saf 2007;30:657-68.

6. Kugman KP, Dagan R. Randomized comparison of meropenem with cefotaxime for treatment of bacterial meningitis. Meropenem Meningitis Study Group. Antimicrob Agents Chemother. May 1995;39:1140-6.
7. Cannon JP, Lee TA, Clark NM, Setlak P, Grim SA. The risk of seizures among the carbapenems: a meta-analysis. J Antimicrob Chemother 2014;69:2043-55.

8. Miller AD, Ball AM, Bookstaver PB, Dornblaser EK, Bennett CL. Epileptogenic potential of carbapenem agents: mechanism of action, seizure rates, and clinical considerations. Pharmacotherapy 2011;31:408-23.

9. Baraboutis IG, Marangos MN, Skoutelis A, Bassaris H. Meropenem-aggravated seizure activity in progressive myoclonus epilepsy. Int J Antimicrob Agents 2008;31:177-9. 